ELORE (ISSN 1456-3010), vol. 15 - 1/2008.

Julkaisija: Suomen Kansantietouden Tutkijain Seura ry.

[http://www.elore.fi/arkisto/1_08/oja1_08.pdf]

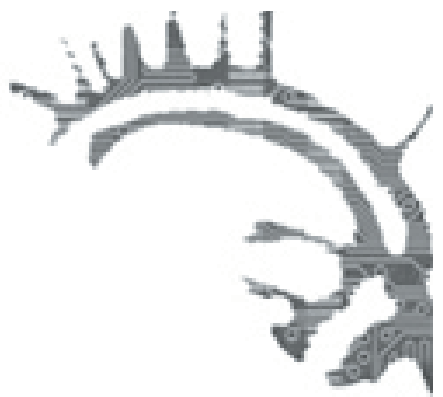

\title{
KENTTÄKOKEMUKSESTA TIEDOKSI
}

\author{
Karoliina Ojanen
}

Ratsastus on suosittu harrastus nuorten naisten ja tyttöjen keskuudessa (ks. Pystynen $2007,177)$. Monet ratsastusta harrastavista tytöistä toimivat tallilla myös hevosenhoitajina, ja talleille onkin muodostunut tyttöjen dominoimia tallityttöyhteisöjä. Tallityttöyhteisö järjestyy hoitamisen ympärille, mutta tytöt tekevät tallilla myös paljon muuta kuin hoitavat hevosia: se on paikka tavata ystäviä ja viettää aikaa "omiensa" seurassa. Toiminta tallilla hevosten ja tyttöjen kanssa tarjoaa tytöille monenlaisia kyvykkyyden, hyväksynnän ja itsenäisyyden kokemuksia, jotka syntyvät sekä kanssakäymisissä hevosen kanssa että erityisesti sosiaalisessa rakenteessa pärjäämisen, yhteenkuuluvuuden ja hierarkiassa etenemisen kautta.

Tallityttöyhteisö muodostaa tytöille oman kulttuurisen tilan. He luovat siinä sellaisia mahdollisuuksia, joita heillä muuten ei ole (Ojanen 2006; ks. myös Tolonen 1992; Kokko 2007, 67-68, 114, 121; vrt. Forsberg 2007, 101). Tallilla tytöt voivat hetkellisesti vapautua valtakulttuurisista normipaineista. Toisaalta vapautuminen toteutuu tallityttöyhteisön tiukkojen normien mukaisesti; näiden noudattaminen on elinehto yhteisöön kuulumisen kannalta. Normeista vapautumisen voi myös tulkita uusintavan valtakulttuurista järjestelmää (Ojanen 2006). Tytöt poikkeavat tallityttöyhteisössä stereotyyppisistä tyttöihin kohdistetuista odotuksista, mutta yhteisössä vallitsevat myös perinteiset kristillis-patriarkaaliset hyveet ja protestanttinen työetiikka (ks. Käyhkö 2006, 122-170).

Valmistelen väitöskirjaa tallityttöjen yhteisöstä ja sen sukupuoliperinteestä. Olen itse toiminut tallityttönä noin kahdeksan vuotta 7-15-vuotiaana. Aktiivisimmillani kävin tallilla viisi kertaa viikossa ja hoidin kolmea hevosta. Tallityttötaustani ja ristiriitaisetkin muistoni tuosta ajasta innoittivat minua valitsemaan väitöstutkimukseni aiheeksi suomalaisten tyttöjen kulttuurin ratsastustallin tallityttöyhteisössä. Tutkimukseni pääaineistona ovat 23 tallitytön teemahaastattelut. Kolmetoista tyttöä on samalta tallilta, jossa olen nuoruudessani käynyt. Kesällä 2006 tein tallilla havainnointijakson, sillä kulttuurinen tieto muodostuu pitkälti myös sellaisesta tiedosta, joka ei ole verbalisoitavissa vaan joka on koettava (esim. Hastrup \& Hervik 1994, 3, 9; Okely 1994, 45). Osallistuva havainnointi perustuu juuri käsitykseen kokemuksellisuuden 


\section{KENTTÄKOKEMUKSESTA TIEDOKSI}

keskeisyydestä tiedon perustana (Rudie 1994, 28). Ajattelin tallityttöyhteisön arjen havainnoinnin täydentävän haastatteluista abstrahoimaani käsitystä tallityttöyhteisön kulttuurisista käytänteistä. Olin tallilla kentällä vain yhden kesän, mitä perustelin sillä, että menneisyyteni ja haastattelujen jälkeen tallityttökulttuuri olisi minulle suhteellisen tuttua. Kaksi kuukautta oli kuitenkin liian lyhyt aika, jotta olisin päässyt yhtäältä vieraudesta ja toisaalta liiallisesta läheisyydestä eroon. Olettamani läheisyys muuntui kentällä usein etäisyydeksi haitallisella tavalla. Huomasin, miten menneisyydestäni ja kulttuurin tuntemuksestani oli paitsi apua myös merkittävää haittaa (ks. esim. Ormond 2004, 243-253).

Tutkijan asemani monipaikkaisuus kävi ongelmalliseksi erityisesti alkaessani analysoida kenttäpäiväkirjaani. Analyysi jähmettyi aluksi lähes neuroottiseen itsereflektioon, kun päiväkirjamerkinnät kirvoittivat runsaasti muistoja kentältä ja omasta ajastani tallilla (ks. Anderson 2006, 380). Aloin pohtia, millä keinoilla kenttäpäiväkirjan tulkinnoista ja kokemuksista kentällä on muodostettavissa tutkimukseni kannalta oleellista analyyttista tietoa ja millä tavoin sitä tulisi analysoida (esim. Hastrup \& Hervik 1994, 1). Miten avaan tiedon ja tulkintojen muodostamisen prosessia? Miten menneisyyteni tallityttönä sekä yhä kiinteä suhteeni hevosiin vaikuttivat siihen, mitä havainnoin, miten tuotin tapahtumia ja miten niitä tulkitsin kenttäpäiväkirjassa ja nyt "täällä" (vrt. Aro 1996, 305-306)?

Analyyttinen ote eli tutkijan monipaikkaisuuteni sekä osallisuuteni ymmärtäminen mahdollistui vasta kaukana karsinoista analyysin ja tulkinnan edetessä (ks. Coffey 1999, 18-31; Gothóni 1997, 143). Refleksiivisyyden avulla sain kiinni siitä, miten monin tavoin osallistuin tallityttöilmiön tuottamiseen ja tulin konkreettisesti osaksi tutkimusta. Tässä artikkelissa tarkastelen tätä prosessia eli tiedon tuottamista ja muotoutumista kenttäkokemuksista refleksiivisyyden kehyksessä.

\section{REFLEKSIIVINEN PAIKANTUNEISUUS}

Refleksiivisyydestä on kirjoitettu paljon erityisesti 1980- ja 1990-luvuilla. (1) Antropologisessa tutkimuksessa on jo pitkään ymmärretty tutkimuksen henkilökohtaisuus, mutta viime vuosina huomio on kiinnittynyt siihen, millä tavoin tuota henkilökohtaisuutta tulisi tai voisi selkeämmin tuoda esiin tutkimustekstissä (Coffey 2002, 313-317; Saukko 2003, 62). Keskustelut paikantuneisuudesta ja refleksiivisyydestä liittyvät näihin kysymyksiin.

Refleksiivisyys ja paikantuneisuus tarkoittavat osittain samoja asioita (esim. Haraway 1988, 575-599; ks. myös Fingerroos 2003; Koivunen \& Liljeström 1996). Paikantuneisuus tutkimuksessa merkitsee, että tutkija asemoi itsensä tieteen kentällä eksplikoimalla tieteenperinteen, josta tutkimusta tekee, sekä oman taustansa niiden asioiden osalta, joiden olettaa olevan työssään olennaisia (ks. Liljeström 2004, 11-13). Refleksiivisyyden tulkitsen merkitsevän näiden asioiden lisäksi tutkijan taustojen aktiivista käsittelyä aineiston analyysin yhteydessä sekä sellaistakin itsetutkiskelua, jota ei kirjoiteta lopulliseen tekstiin. 


\section{Karolitna Ojanen}

Paikantuneisuudesta on feministisessä metodologiassa tullut objektiivisuuden edellytys: objektiivisuuden saavuttamiseksi tutkijan on eksplikoitava, mistä näkökulmasta hän tutkimusta tekee. (2) Juuri subjektiiviset lähestymistavat mahdollistavat objektiivisuuden: kun tutkimus paikannetaan, sitä voidaan myös arvioida (esim. Behar 1996; Keller 1988). (3) Subjektiiviset lähestymistavat merkitsevät tässä esimerkiksi oman tallityttömenneisyyteni tarkastelua suhteessa kenttäpäiväkirjan havaintoihin.

Paikantuneisuus jää joskus vain pinnalliseksi tutkijaa koskevien määreiden luettelemiseksi, joka ei näy tutkimuksessa muualla kuin johdannossa. Jotta subjektiiviset lähestymistavat mahdollistaisivat objektiivisuuden eli edellytyksen arvioida työtä kokonaisvaltaisesti, tulisi paikantuneisuuden olla refleksiivistä. Tässä artikkelissa avaan tätä näkemystä siitä suunnasta, miten kenttäaineiston tulkinnassa harjoittamani refleksiivisyys ja pyrkimys oman tallityttöyteni avoimempaan käsittelyyn antavat paitsi itselleni myös toivottavasti lukijoille enemmän välineitä arvioida tutkimuksessani tekemiä tulkintoja.

\section{KENTTÄAINEISTON ANALYSOINTI VÄLIMAAILMANA}

Tässä artikkelissa refleksiivisyys merkitsee prosessia, jossa tutkija käy läpi, miten hänen sosiaalinen taustansa konstruoi hänen uskomuksiaan ja miten nämä uskomukset vaikuttavat siihen, mitä ja miten tutkija havainnoi, nimeää merkityksiä ja tulkitsee toimintaa (Myerhoff \& Ruby 1982, 1-7; Wasserfall 1997, 152; myös esim. Järviluoma ym. 2006, 310). (4) Refleksiivisyys merkitsee tässä artikkelissa kykyä arvioida omien uskomuksieni ja oletusteni vaikutusta kentän tapahtumiin ja niistä tekemiini tulkintoihin.

Refleksiivinen analyysitapa ei kuitenkaan sinällään riitä tiedon kriteeriksi, eikä tutkija voi oikeuttaa tieteellisiä oletuksiaan vetoamalla pelkästään omaan yhteiskunnalliseen taustaansa ja muihin häntä paikantaviin tekijöihin (Rolin 2005, 101). Refleksiivisyys on ymmärrettävissä olemuksellisesti vuorovaikutuksellisena prosessina. Se viittaa maailmaan "meidän" ja "toisten" välillä (Hervik 1994, 91-92). Refleksiivisyyden avulla voin saavuttaa tuon suhteen eli maailman minun ja tallityttöjen välillä. Tämä vuorovaikutteinen "välimaailma" on tutkimuksen kohde ja se, mitä tutkimus voi saavuttaa. Jos näin on, voisi ajatella, että mitä paremmin tieto on reflektoitu, sitä hienosyisemmin tutkittava ilmiö aukeaa. Tutkimus kertoo tutkijan suhteesta tutkittavaan ilmiöön, ilmiöstä sellaisena kuin se tutkijan kanssa oli, jolloin tutkijan refleksiivisyys voi olla ratkaisevassa osassa kattavamman kuvan antamisessa tutkimuskohteesta.(5) Samantyyppisesti Paul Atkinson on huomauttanut, että refleksiivisyys ei tarkoita vain tutkijan löyhää itsetutkiskelua. Sen sijaan tutkija on läpikotaisin osa ilmiötä myös siinä merkityksessä, että tutkittava ilmiö ei ole olemassa riippumattomana tutkijasta (Atkinson 2006, 402.)

Atkinsonin määrittelemä refleksiivisyys ja käsitys tutkimuksesta välimaailmana lähenevät Karen Baradin (1998) agentiaaliseen realismiin lukeutuvan intra-aktion käsitettä, jonka mukaan maailma tulisi hahmottaa jakautumattomina ilmiöinä; näin ollen erottelu kohteeseen ja havaitsijaan ei ole tarpeellinen. (6) 


\section{KENTTÄKOKEMUKSESTA TIEDOKSI}

Intra-aktion idea on kehittelemisen arvoinen suhteessa käsitykseen refleksiivisyydestä vuorovaikutuksellisena prosessina, jolla on merkittävä osa tiedon muodostuksessa. (7) Baradin ja Hervikin näkemyksiä yhdistämällä tutkimuksen voi tulkita olevan intra-aktiivista välimaailman kuvausta, jolloin tutkimuksen kohdetta ei voi täysin palauttaa tutkijaan eikä tutkittavaan. Refleksiivinen analyysi valottaa tutkijan lähtökohtia tulkinnoilleen, mutta tulkinnat eivät ole palautettavissa vain tutkijaan vaan ne ovat suhteessa kentän toimijoihin. Vaikka tässä artikkelissa käsittelen refleksiivisyyttä tarkastelemalla kenttäpäiväkirjaan tekemiäni tulkintoja nimenomaan suhteessa minun positioihini, niin samalla ymmärrän tutkimuksellisen tiedon olevan aina intra-aktiivisesti vuorovaikutuksessa muodostunutta. Tästä näkökulmasta tutkijan omien positioiden analyysi on nimenomaan ovi tutkimuskohteen tavoittamiseen ja ymmärtämiseen. Koska tutkimus kertoo tutkijan ja tutkittavan välimaailmasta, refleksiivisyydellä on merkittävä osa siinä, millaista tietoa lopulta tuotetaan. Tutkija voi juuri refleksiivisen eriytymisen kautta eli hahmottaessaan kentällä muodostamiaan identiteettejä päästä käsiksi tuohon välimaailmaan, "keitä minä ja tutkittava silloin siellä kentällä olimme” (ks. Aro 1996).

\section{REFLEKSIIVISYYS: OVIA JA PEILEJÄ}

Tutkimus on tietyssä mielessä aina tutkimusta myös tutkijasta (esim. Whitehead \& Conaway 1986, 8-9, 402). Ruth Behar (1996) on käsitellyt refleksiivisyyttä haavoittuvana (engl. vulnerable) kirjoittamisena, jossa tutkija käyttää hyväkseen tunteenomaisia kytköksiään tutkimuskohteeseen. Beharin mukaan tutkijan tunteet ovat lähtemätön osa tutkimusta. Hän painottaa, että jos tutkija asettaa tekstissä itsensä alttiiksi ja on haavoittuva, lukijat reagoisivat tekstiin samalla tavalla, eli tekstin lukeminen saisi aikaan tunteita. Tunteet tarjoaisivat tien tieteelliseen ymmärtämiseen (ks. myös Anderson 2006, 385). Haavoittuvainen kirjoittaminen ei merkitse loputonta omien tunteiden läpikäymistä. Ymmärrän sen viittaavan siihen, että tutkija havaitsee, mitkä oman itsen piirteet ovat ne kehykset, joiden läpi tutkittavaa ilmiötä tarkastelee. Käytännössä tämä tarkoittaa sitä, että tutkijan itsemäärittelyllä vaikkapa entiseksi tallitytöksi, keskiluokkaiseksi, valkoiseksi naiseksi, joka tutkii tallityttöjä, ei ole merkitystä, jos tutkijalla ei ole kykyä analysoida syvemmin henkilökohtaisen kokemuksensa ja tutkittavan kulttuurin suhdetta. (Behar 1996, 13-16; ks. myös Järviluoma ym. 2006; Myerhoff \& Ruby 1982, 6.) Soveltaessani näitä ajatuksia kenttätyöhöni alkoivat kenttäpäiväkirjaani kirjoittamani tulkinnat ja muistot kentältä hahmottua toisella tavalla.

Tytön sosiaalista asemaa tallityttöyhteisön hierarkiassa määrää se, millaisena hoitajana häntä pidetään: hyvänä vai huonona. Kärjistäen ilmaisten hyvät hoitajat ovat "vanhempia" ja huonommuus liitetään "nuorempiin" hoitajiin. Hoitajan maine ei ole kuitenkaan kiinni vain kokemuksesta ja hoitotaidoista. Lieväkin poikkeama yhteisön normeista johtaa tytön sulkemiseen yhteisön ulkopuolelle ja häntä aletaan pitää "huonona hoitajana". Hoitamisen merkitys ei ole yksiselitteinen, vaan hevonen symboloi monin tavoin yhteisön rajaa (vrt. Douglas 1966). Hevonen on yhteisössä 


\section{Karolitna Ojanen}

mittari, jonka avulla tallitytöt järjestävät yhteisön sosiaalista ja hierarkkista rakennetta. Tyttöjen yksilölliset suhteet hevosiin nivoutuvat hevosen yhteisölliseen merkitykseen. Tyttöjen hevossuhteet ovat läheisiä ja luottamuksellisia, ja niihin kytkeytyy tunne hyväksytyksi tulemisesta, mutta samanaikaisesti ne ovat täynnä eritasoista, myös väkivaltaista, hallintaa. Aineistoni mukaan suhteet hevosiin tuottavat tytöille monin tavoin kompetenttiuden kokemuksia: hevosen hallinta ja läheisen suhteen luominen tuottavat tytölle yksilöllisellä tasolla pärjäämisen ja hyväksynnän tunteita, mutta samalla ne tuottavat samoja vaikutuksia myös yhteisöllisesti ja voivat vahvistaa tytön asemaa yhteisössä. Hoitohevosen saaminen on ensimmäinen edellytys tytön yhteisölliselle subjektiudelle ja se toimii ryhmän jäsenyyden merkkinä. Se, mitä hevosta hoitaa ja minkälaisen suhteen hevoseen kykenee luomaan, erottelee vielä tarkemmin kunkin tytön asemaa hoitajayhteisössä. Hyvän hoitajuuden yksi edellytys on noudattaa tallityttöyhteisön uhrautuvaa eetosta ja tähän liittyvää tehtävistä kieltäytymisen kieltoa (esim. Ojanen 2005).

Kerran harjatessani tuntihevosta tallin työntekijä tuli kysymään minulta, voisinko tehdä hänen puolestaan yksityisten hevosten ruokintaan liittyviä tehtäviä (Kenttäpäiväkirja 25.7.2006). (8) Myönnyin, vaikka olin epävarma, onko minun yleisesti hyväksyttävää tehdä nuo tehtävät. Yksi tallitytöistä ihmetteli, miksi olen niï kiltti, että suostun aina tekemään kaiken. Vastasin syyksi jotakin epäselvää tallitytön menneisyydestäni. Tuntiavustaja alkoi haukkua tallin nykyisiä hoitajia laiskoiksi nuoremman tallitytön kuunnellessa vieressä. Otin esille haastatteluissa esiin tulleen normin siitä, että tallilla tehtävistä töistä ei saisi kieltäytyä. Korostin sitä, miten olen ymmärtänyt, että ei saa sanoa ei, sillä olin kuullut, että tytöt saattoivat piiloutua heinävarastoon tai jopa laitumen ojaan välttyäkseen taluttamiselta. Seurassamme ollut tallityttö kertoi nauraen itse myös piiloutuneensa kerran kuumalla ilmalla hoitajien tarvikkeiden säilytystilaan. Tällaisia tapauksia on tullut esiin erilaisin variaatioin haastatteluaineistossa (esim. Milja 13.2.2005; Satu 5.5.2005; Sanna 11.5.2005).

Sovimme avustajan kanssa, että teen nuo työt sinä aikana, kun hän on auttamassa ratsastajia. Olin menossa hakemaan kottikärryjä tallin yksityispuolelta, jonne asiattomilta on pääsy kielletty. Huomasin tallinomistajan seisovan kottikärryjen vieressä. En yksinkertaisesti voinut mennä hakemaan niitä, koska kuvittelin joutuvani selittämään hänelle, mitä teen sillä puolella. Mietin, että mieluummin valehtelen tuntiavustajalle kuin selittelen tekemisiäni omistajalle, joka on minut tallilleen päästänyt. Poistuin autolleni ja lähdin tallilta. Ajaessani ihmettelin käytöstäni. En vain sitä, että olin pettänyt avustajan luottamuksen tai että pelästyin omistajaa niin voimakkaasti, vaan enemmän sitä, että toteutin tuota vastaan sanomisen kiellon normia. En minäkään uskaltanut sanoa ei, mutta ojaan piiloutumisen sijasta ajoin autolla pakoon.

Beharin (1996, 12-16) haavoittuvan etnografian idea avasi silmäni tutkimuksen tunteenomaisuudelle. Yllä kuvaamani tilanne näytti minulle, miten keskeisellä tavalla olen aktiivisesti osa tutkimusta ja miten kentän tapahtumien refleksiivinen analysointi on ratkaisevan tärkeää yhteisöstä tekemieni tulkintojen kannalta. Nämä ovat ne kehykset, joiden puitteissa tutkittavaa ilmiötä tarkastelen. Esimerkissä en mennyt hakemaan kottikärryjä, koska minussa heräsi tunnetasolla nuorena tallityttönä omaksumani sääntö tilojen ja tehtävien järjestyksestä ja lapsenomainen pelko 


\section{KENTTÄKOKEMUKSESTA TIEDOKSI}

omistajaa kohtaan. Onhan mahdollista, että pelkoni ja perääntymiseni olisivat täysin irrationaalisia yhteisön nykyisessä järjestyksessä, pelkkää muistojeni mielikuvitusta. Esimerkki osoitti, miten voimakkaasti tallityttömenneisyyteni vuoksi vaikutan kentän tapahtumiin, ja tulkitsen sitä aivan tietyllä tavalla.

Emotionaalisia kytköksiä ei tutkimuksessa kannata väheksyä, koska ne voivat tarjota kohteesta myös uutta tietoa. Amanda Coffey (1999) painottaa, että tutkijan olisi hyvä tiedostaa, miten emotionaalinen ja henkilökohtainen koko tutkimusprosessi on, mutta tämä ei edellytä, että tulisi alkaa kirjoittaa henkilökohtaisemmin. Refleksiivisen pohdinnan ei siis ole pakko olla näkyvissä. Mutta myöskään se, että tutkija ymmärtää olevansa osa tutkittavaa kulttuuria ja pohtii tätä refleksiivisyyttä tutkimuksessa julkisesti, ei tarkoita, että tutkijan itsestä tulee tutkimuksen keskipiste, kuten äärimmäisen autoetnografisissa tutkimuksissa. (9) Refleksiivisyys tarkoittaa kohdallani aineiston tulkinnan tapaa: käytän tulkintojeni muodostamisessa myös omaelämäkerrallista ainesta, koska olen ollut jäsen tutkimassani yhteisössä (vrt. esim. Suojanen 1997). Seuraavassa kentältä poimimassani esimerkissä tarkastelen, miten emotionaaliset muistot tuottivat minulle yhden keskeisen oivalluksen tallityttöyhteisöstä.

Ratsastuksenopettajat olivat kehottaneet minua harjaamaan hevosia, jos en keksisi tallilla muuta tekemistä. Kerran harjatessani eräs opettajista tuli luokseni ja sanoi: "ihme, että löysit vielä puunattavia, vaikka nuo tytöt harjasi niitä koko päivän aamun kurssilla.” (Kenttäpäiväkirja 11.8.2006.) Lopetin harjauksen ja lähdin vähin äänin autolleni "kirjoittamaan muistiinpanoja", vaikka todellisuudessa menin sinne tilanteen aiheuttaman nolostumisen vuoksi (vrt. Coffey 1999, 100). Vakuuttelin itselleni, että hevoset todella olivat olleet likaisia. Istuessani autossa näin taustapeilistä, miten ratsastajat tämä nimenomainen opettaja mukanaan liikkuivat jonossa ratsastustunnille. Silloin yhtäkkiä oivalsin, mistä nolostumisessani oli ollut kyse.

Taipumukseni tulkita opettajan sanominen kritiikkinä kertoo siitä, miten nuorena tallityttöyhteisön koin, sillä yhtä hyvin opettajan huomautusta olisi voinut pitää tässä tilanteessa esimerkiksi tunnustuksena. Nolostumiseni johtui siitä, että en ollut ottanut tavakseni hoitaa tallin hevosia pelkästään hevosten likaisuuden vuoksi vaan pikemminkin halusin olla "hyvä ja kunnollinen" hoitaja samalla tavalla kuin ollessani 13-15-vuotias. Kun tämä pyrkimys ei mielestäni toteutunut, se aiheutti minussa häpeää. Tätä tapausta analysoimalla ymmärsin, miten tallityttöjen haastatteluissa kuvaamat tilanteet hevosten uhrautuvasta hoitamisesta, tallityttöryhmien sosiaalisista suhteista tai yleensä yhteisön sosiaalisissa verkostoissa toimimisesta kiteytyvät pyrkimykseen tulla hyväksytyksi sekä hevosten että ihmisten kanssa. Tuntiessani kentällä jo omilta tallityttöajoiltani tuttua häpeää saavutin kokemuksellisesti yhden tallityttöyhteisössä toimimisen merkityksistä (ks. Coffey 2002, 319). Tällaisen kivuliastakin häpeää tuottavan kokemuksen refleksiivinen analyysi mahdollisti uutta tietoa: koin ymmärtäväni, mistä nykyisessä tallityttöyhteisössä oli kyse ja mitä tytöt olivat pyrkineet minulle yhteisön todellisuudesta viestimään kuvatessaan yhteisöä ja suhdettaan hevosiin. (10)

Michael Schwalbe (1996, 58-82) kuvaa, miten hän saavutti uutta ymmärrystä tutkimuskohteestaan reflektoidessaan oman elämänhistoriansa valossa reaktioitaan tutkittavaan ilmiöön. Schwalbe nimeää jokaisen oivalluksen sekä oveksi että peiliksi: oivallus on tapa nähdä sekä tutkittavien kokemuksiin että omaansa. Samanlainen 


\section{Karolitna Ojanen}

oven ja peilin kaksoisliike on tunnistettavissa juuri esimerkiksi edellisessä tapauksessa. Oivalluksen kautta saavutin sekä ymmärrystä tutkittavasta yhteisöstä että samalla itsestäni nuorena tallityttönä ja tuon tallityttöidentiteettini vaikutuksesta tutkimukseni tekemiseen.

Tällaisia kenttätapauksia en kuitenkaan kirjoita näkyviin tutkimustekstiin, koska ne veisivät liikaa huomiota tallityttöjen itse haastatteluissa nimeämistä talliyhteisön merkityksistä ja kuvauksista. Tästä syystä en kuljeta näitä refleksiivisiä prosesseja mukana koko matkaa, vaikka tuon oman paikkani joissain kohdin esille. Vaikka refleksiivisiä prosesseja ei kirjoittaisi näkyviin, on niiden implisiittinenkin käsittely kuitenkin merkittävää ilmiön ymmärtämisen kannalta. Tässä halusin osoittaa, miten hiljainenkin itsen analyysi antaa välineitä tuottaa tietoa toisella tavalla kuin jos olisin kiertänyt tapauksen ja kieltänyt häpeän tunteeni. Toiseksi tällaisten tilanteiden analyysi alleviivaa minulle niitä näkökulmia ja lähtökohtia, joista tallityttöilmiötä tulkitsen. Tällaisen refleksiivisyyden avulla on mahdollista yrittää tehdä vielä tietoisempia tulkintoja, suhteuttaa niitä omaan henkilöhistoriaan ja arvioida, mikä on oleellista tallityttöyhteisön ymmärtämisen kannalta ja mikä taas ainoastaan oman menneisyyden tapahtumien uudelleen elämistä. Tätä kautta toivon tavoittavani tulkintoihin lisää tukevuutta.

\section{TutKITTAVAA KULTTUURIA TUOTTAMASSA}

Saadessani kiinni refleksiivisyyden merkityksestä aloin tutkia, miten muualla päiväkirjassani olin hahmottanut tallityttöyhteisöä. Toisen havainnointipäivän päätteeksi päättelin, että nykyiset hoitajat ovat "huonoja"(kenttäpäiväkirja 21.6.2006). Vertasin heidän hoitotapojaan muistoihini omista hoitotavoistani sekä haastatteluissa esiin tulleeseen ideaaliin (ks. Suojanen 1997, 154-155). Kentän epäyhtenäisyyttä verrattuna haastatteluihin ja jo muodostamiini tulkintoihin oli vaikea sietää. Henkilökunta vahvisti tulkintaani kulttuurin muuttumisesta päivitellen, miten hyviä hoitajia ei enää nykypäivänä ole. Puhetta väritti sama uhrautumisen tendenssi, joka tuli esiin nykyisten tallityttöjen haastatteluissa keskeisenä osana hoitajaideaalia.

Vaikka tiedostin käsitykseni hoitajuudesta olevan ideaalinen, suhtauduin siihen kentällä yhtä tosissani ja sokeasti kuin 15-vuotiaana ollessani osa yhteisöä vanhempana tallityttönä. Aloin sääliä tuntihevosia, ja lopulta tulkintani hoitajien huonoudesta johti siihen, että aloin tarkkailla tyttöjen hoitotapoja ja huomautella heille, miten hevosia kuuluisi hoitaa (ks. Coffey 1999, 5; Fine 1987, 228-230). Käskin heitä esimerkiksi harjaamaan paremmin, siivoamaan karsinoita tai poistumaan käytäviltä hevosten ruokailun ajaksi. Aloin myös itse hoitaa monia hevosia, ja esimerkiksi joinakin päivinä siivosin kymmenenkin karsinaa.

Näissä tilanteissa tuotin äärimmäisellä tavalla sitä kulttuuria, jota olin tullut tutkimaan. Tiedostin, että osallistuva havainnointi ei tarkoittanut tällaista "osallistumista", mutta en silti pystynyt lopettamaan. Kenttäpäiväkirjassani on itselleni kirjattuja kehotuksia siitä, että nyt tarkkailet sitä ja sitä ja pysyt sivussa, mutta heti seuraavana päivänä valuin taas tuohon sosiaalista hyväksyntää tuottavaan tilanteeseen 


\section{KENTTÄKOKEMUKSESTA TIEDOKSI}

eli komentamaan itseäni nuorempia. Puolustin käytöstäni itselleni vetoamalla siihen, että toimin näin päästäkseni sisään yhteisöön. Koska vanhemman hoitajan rooli oli minulle sopivin, minun kannattaisi toimia sen mukaisesti. Käytin valtaa negatiivisesti, joskin sillä joskus oli positiivisia vaikutuksia: tytöt kysyivät minulta useasti apua ja opetin heille asioita, jotka lisäsivät heidän tilaansa yhteisössä.

Analyysin edetessä ymmärsin, miten syvästi kenttätyön aikana hahmotin myös omaa aikaani tallilla, joka selittää paitsi tulkintojani myös tallityttöjen hoitotapoihin puuttumista. Tämän asian paikantaminen ja ruotiminen antoi välineitä tarkastella näinkin tuttua tutkimuskohdetta, ei vain minun suhdettani siihen (Coffey 1999, 158; ks. myös Nyström 2007).

\section{TALLITYTÖN JA TUTKIJAN VUOROTTELUSSA}

Huonon hoitajuuden lisäksi totesin päiväkirjassani yhteisöstä puuttuvan vanhemmat tallitytöt, vaikka tallityttöjen jako vanhempiin ja nuorempiin (eli hyviin ja huonoihin) on keskeisin sosiaalinen erottelu yhteisön järjestämisessä. Myöhemmin lukiessani päiväkirjaa ymmärsin, että nämä tulkintani olivat vinoutuneita. Ne olivat seurausta liiasta läheisyydestä ja kaukaisuudesta samanaikaisesti (ks. liian lähellä tehdystä tulkinnasta Cassidy 2002, 120). Yhtäältä minusta oli tullut aikuinen, joka ei onnistunut "näkemään" ja tavoittamaan tyttöjen kulttuurisia merkityksiä. Olin niin vanha, että ajat "silloin ennen" näyttivät paremmilta ja "nykynuoriso rappeutuneelta". En ymmärtänyt, että 13-15-vuotiaat tallitytöt ovat yhteisön vanhimpia jäseniä tai että tytöt suhtautuvat hyvin vakavasti hoitohevoseen ja hoitamiseen. Analysoidessani aineistoa huomasin, miten tallilla oli hevosia, joihin en uskaltanut edes koskea juuri siitä syystä, että niiden hoitajat vahtivat niitä tarkasti. On oireellista, että en tavoittanut kentällä, miten nämä tulkinnat eivät olleet seurausta hoitokulttuurin muutoksesta vaan eläytymisestäni vanhemmaksi tallitytöksi, jolloin nuorempien tyttöjen hoitaminen ei muulta voinut näyttääkään kuin huonolta (vrt. Gothóni 1997, 141). Sama positio oikeutti myös puuttumisen tyttöjen toimintaan.

Voimakas identifikaationi tallitytöksi tuotti vääristyneitä käsityksiä tallityttöyhteisöstä: kävin kentällä läpi tunteita, joita olin tuntenut ollessani aikoinani vanhempi tallityttö ja tulkitsin tapahtumat siitä käsin. Vääristyneellä tai vinoutuneella tarkoitan tässä käsitystä, joka ei tavoittanut tutkittavan yhteisön toimijoiden eli tallityttöjen merkityksiä vaan pohjasi yksioikoisesti muistoihini ajastani tallityttönä. Tutkittavaa tallityttöyhteisöä tulkinnat eivät kuvanneet. (11)

Analyyttisen tiedon muodostuminen kenttäaineistosta tulee näkyviin näissä väärinymmärryksissä. Kenttäpäiväkirjaan kirjaamieni asioiden oikaisu osoittaa, miten refleksiivisen otteen avulla kenttäjaksosta voi muodostaa oleellista analyyttista tietoa. Etnografisessa tutkimuksessa ei ole heikkous, jos tutkija sisäistyy tutkimaansa maailmaan. Heikoksi tutkimuksen voi tehdä se, jos tutkija ei ymmärrä omien identiteettiensä ja asemiensa moninaisuutta ja muodostumista sekä vaikutusta kenttätyössä. (Coffey 1999, 36-37.) 


\section{Karolina Ojanen}

Ratkaisevaa on se, että palauduin ja jopa taannuin tallitytöksi enkä siksi kyennyt havainnoimaan tyttöjen toimintaa kunnolla tai analysoimaan päiväkirjaa aluksi muusta positiosta. Tämän taantumisen ymmärtäminen oli keskeinen seikka tutkijuuteni uudelleen tavoittamisessa. Olin kentällä samanaikaisesti liian lähellä identifioituen tallitytöksi ja toisaalta liian kaukana, koska olin aikuinen tutkija, joka ei kyennyt tavoittamaan tyttöjen maailmaa ja sen merkityksiä. Useasti menneisyyteni tallityttönä vaikutti siihen, että keskityin liikaa itseeni ja reaktioihini eri tilanteissa, vihantunteisiin, ärtymykseen, häpeään ja sääliin. Toisaalta menneisyyteni antoi minulle mahdollisuuksia ymmärtää tallityttöyhteisön kulttuurin merkityksiä kokemuksellisella tasolla ja aistimuksellisesti (ks. Coffey 1999, 73; Okely 1994, 45-49). (12) Yksi esimerkki tällaisesta kokemuksellisesta tiedosta on, kun autoin erästä isää satuloimaan tyttärelleen hevosen ratsastustunnille. Isä valitti, että hevonen on ihan mahdoton eikä avaa suutaan kuolaimia varten. Otin suitset isältä ja pujotin ne sulavasti hevosen päähän. Olin tyytyväinen taidoistani, ja tämä tapaus antoi minulle aavistuksen siitä, minkälaisia tunteita tällainen kyvykkyys nuoremmissa tytöissä voi herättää: talli on tyttöjen hallinnoima oma tila, jossa ylittää aikuiset ja isät. (Kokemusten saavuttamisesta esim. Davies 1999, 201; ks. Gothóni 1997.)

Sekä Behar että Coffey painottavat, että tutkijan omaelämäkerta voi olla tutkimuksessa mukana ja että tutkimus on lähtökohdiltaan hyvin henkilökohtaista. Se, että tutkimus on identiteettityötä, ei kuitenkaan tarkoita, että elämäkerrallisia elementtejä tarvitsisi käyttää tutkimustekstissä tai että tulisi välttämättä kirjoittaa henkilökohtaisemmin (Coffey 1999, 1-5, 23). Lisa Adkins (2002) on huomauttanut, että refleksiivinen ote tai kompleksisempi itseymmärrys ei automaattisesti ole tae paremmasta tutkimuksesta tai vastaus kaikkeen (ks. myös Behar 1996, 14). Refleksiivisestikin tuotettu tulkinta on kuitenkin tulkinta aina jostakin tietystä paikasta, eikä henkilökohtaisen aineksen käsittely aina tuota uusia oivalluksia. Tutkittava ilmiö ei koskaan ole kokonaan tyhjennettävissä, oli tutkija miten refleksiivinen tahansa. (Adkins 2002, 332-347; myös Coffey 2002, 317.)

Tutkijan omaelämäkerralliset tekijät olisi siis suhteutettava tutkittavaan ilmiöön, sillä vain siten ne voivat tarjota siitä uusia oivalluksia (Coffey 1999, 158, 317). Tärkeää olisi, että tutkija ymmärtää suhteensa tutkittavaan ilmiöön ja osaa arvioida suhteen vaikutuksen tulkintoihin. Tätä periaatetta konkretisoin tarkastelemalla vielä yhtä kenttäkokemusta.

\section{ERÄS TUTKIJAKSI TULEMINEN}

Saapuessani ensimmäisenä päivänä tallin satulahuoneeseen tallin opettajat, Ulla ja Elina, istuivat suunnittelemassa päivän tunteja. Olin aiemmin käynyt sopimassa Ullan kanssa havainnointijaksosta ja soittanut hänelle vielä edellisellä viikolla, mutta nyt hän ei tervehtinyt minua tai antanut minulle mitään töitä vaikka olimme sopineet, että toimisin tietynlaisena ratsastajien avustajana tallilla. Tervehdin heitä ja kysyin, mitä voisin tänään tehdä. Ulla katsahti minuun ja sitten pää painettuna papereihinsa sanoi 


\section{KENTTÄKOKEMUKSESTA TIEDOKSI}

Elinalle, että 'Karoliina on tekemässä täällä (epäselvää) jotain ja tarkoitus olla vähän niin kuin avustaja" (Kenttäpäiväkirja 20.6.2006). Kerroin hieman vaivaantuneena, mitä olen tekemässä pyrkien luomaan kontaktia Elinaan, jota en opettajista ollut siis aiemmin tavannut. Elina ei kuitenkaan katsonut minua vaan sanoi Ullalle väsyneesti, matalalla, monotonisella äänellä: 'En tiedä mitä kaikkea porukkaa täällä on tänä kesänä, en tiennyt, että se yksikin tinttarella on täällä tämän kesän”. (Kenttäpäiväkirja 20.6.2006.) Myöhemmin minulle selvisi, että "tinttarellalla" hän viittasi tallilla työskentelevään naiseen, josta ei yhteisössä juuri pidetty.

Tulkitsin ratsastuskoulun opettajien ylenkatsovan asenteen tuottavan ja ilmaisevan tallityttöyhteisön hierarkkista ja normatiivista rakennetta. Tämä etäännyttävä tulkinta oli näin jälkeenpäin katsottuna minulle tapa selviytyä siitä ärsyyntymisestä ja häpeästä, jota vuorovaikutus kentällä aluksi tuotti ja johon liittyivät myös muistoni ajasta, jolloin olin pieni ja ujo tallityttö. Tulkintani "opettajien vihamielisyydestä" vaikuttaa nyt absurdilta. Siinä unohtui roolini yhteisössä ensisijaisesti tutkijana, jollaisena minut otettiin vastaan. Tämä kaikki vaikutti myös kentän tapahtumiin.

Kentälle saapumisessa yleinen kokemus on tietty nolous, häpeä ja jopa pelko (esim. Conaway 1986, 53; Kortteinen 1992). Nämä tunteet ovat seurausta ennen kaikkea tilanteen luomista puitteista: tutkijalla ei ole paikkaa kuin sosiaalisten konventioiden ulkopuolella. Unohdin, että heille edustin tutkijaa huolimatta siitä, miten epävarma itse siitä ehkä olin. Tämän muistaminen olisi oleellisesti muuttanut tapahtumista tekemiäni tulkintoja ja suhtautumista niihin. Esimerkiksi se, että en mielestäni saanut riittävästi töitä, olisi näyttäytynyt toisella tavalla: tuskin henkilökunnan tai vanhempien hoitajien oli mutkatonta alkaa käskeä aikuista yhteisön ulkopuolista tutkijaa. Yksinkertaistin yhteisön jäsenten reaktioiden merkitsevän ja ilmaisevan yhteisön hierarkkista järjestystä. Oman kulttuurin tuntemukseni ja siis tallitytöksi taantumiseni vuoksi en tuossa tilanteessa yltänyt etäisempään positioon. Yhteisö on hierarkkinen, mutta minuun kohdistunut käytös ilmaisi luultavasti molemminpuolista ihmetystä, varautuneisuutta, kiusaantuneisuutta ja erilaisia jännitteitä, joita olin myös mukana tuottamassa. (ks. Coffey 1999, 32, 36-37; Hertz 1997, viii.) Ignoroivaksi tulkitsemani käytös saattoi olla yhteisön jäsenille mutkattomampaa toteuttaa, koska yhteisö on niin hierarkkinen ja sen normatiivinen kommunikaation tapa perustuu erilaisiin rajantekoihin, mutta kentälle saapumisessani ei kyse ollut hierarkkisen rakenteen tuottamisesta.

\section{REFLEKSIIVISYYS METODINA}

Refleksiivinen tutkimusote antaa välineitä hahmottaa ja tavoittaa tutkittavaa ilmiötä eli tutkijan ja tutkimuskohteen vuorovaikutteista ja intra-aktiivista välimaailmaa. Etnografin itseä ei voi erottaa kenttätyöstä tai kenttätyön analyysista, mutta tämä ei merkitse, että hyvä tutkimus olisi täynnä itseymmärryksen auki kirjaamista ja omaelämäkerrallisia tekijöitä. Tutkijan tunteita ja kokemuksia voi käyttää myös implisiittisemmin tutkittavan ilmiön ymmärtämisessä. (Coffey 2002, 158-162; 317-318; Anderson 2006, 383-384.) Koska etnografin itseä ei tutkimuksesta voi erottaa, tulisi refleksiivistä 


\section{Karolitna Ojanen}

paikantuneisuutta vaatia ja vaalia tutkimuksissa yhä enemmän ja refleksiivisyyden käytäntöjä yhdenmukaistaa ja kehittää.

Refleksiivisyys merkitsee sen huomioimista, miten jotkut osat tutkijan itsestä ovat vaikuttaneet tutkimukseen ja kenttäpäiväkirjan tulkintoihin ja miten kentän tapahtumat eivät olisi tapahtuneet samalla tavalla ilman tutkijaa (Behar 1996). Refleksiivisyys voidaan Peter Hervikin mukaan nähdä keskeisenä tapana muuntaa sosiaaliset kokemukset antropologiseksi tiedoksi. Se tarjoaa yhteyden jaetun sosiaalisen kokemuksen ja laajemman kulttuurisen ymmärtämisen välille. Hervikin käsityksen mukaisesti refleksiivisyys ei siis merkitse ainoastaan sitä, että tutkija tutkii omaa paikkaansa, tunteitaan ja kokemuksiaan suhteessa tutkimuskohteeseen ja tekstien tuottamiseen vaan refleksiivisyys on kenttätyön intersubjektiivinen konteksti. (Hervik 1994, 79; ks. Angrosino \& Perez 2000, 673-676). Tulkitsen tämän merkitsevän, että refleksiivisyys on edellytys tutkimukselle ja tutkimuskohdetta eli maailmaa "meidän ja toisten" välillä ei ole ilman refleksiivisyyttä. Täten voisi olla hyödyllistä pohtia, miten refleksiivisyyttä voisi opettaa ja kehittää järjestäytyneemmän metodin suuntaan, koska sen merkitys tiedon muodostamisessa on niin keskeinen (ks. Hatakka 2004, 92-93). Refleksiivisyys mahdollistaa kenttäkokemuksen työstämisen analyyttiseksi tiedoksi, mutta sen mielekäs käyttäminen vaatisi mielestäni tarkempaa ohjeistusta ja koottuja käytännön esimerkkejä siitä, miten sitä voisi hedelmällisesti käyttää ja mitä sillä oikein tarkoitetaan (ks. Fingerroos 2003). Refleksiivisen analyysin kohdalla voi esimerkiksi ihmetellä, kuinka paljon ja millaisia kysymyksiä tutkijan kannattaisi esittää, jotta reflektio aukeaisi tuottoisalla tavalla (ks. Järviluoma ym. 2006, 311). Entä missä määrin tällaista prosessia tulisi kirjoittaa tutkimustekstiin, jos ollenkaan? Auki kirjoitetuista ohjeista voisi olla hyötyä sekä tutkijoille että opiskelijoille, mutta ohjeiden laatiminen ei ole kuitenkaan tämän artikkelin aihe.

Kenttäpäiväkirjan analyysissa onnistuin - joskus tuskallisenkin - refleksiivisen pohdinnan avulla suhteuttamaan tutkittavaan ilmiöön omaelämäkerralliset tekijät, mikä tarjosi tutkittavasta yhteisöstä uutta tietoa. Refleksiivisyys mahdollisti sen, että kykenin etäännyttämään itseäni kenttäpäiväkirjani tulkinnoista ja tulkitsemaan uudelleen esimerkiksi kokemuksiani ignoroivasta asenteesta yhteisön rakenteen ilmentäjänä. Kulttuurinen läheisyys kääntyi refleksiivisen otteen ansiosta kenttäpäiväkirjan analyysissa lopulta eduksi. Sen kautta tavoitin tärkeää tietoa yhteisöstä ja kykenin arvioimaan uudelleen päiväkirjan tulkintojani (ks. Aro 1996). Omien tunteiden peilaaminen kenttäpäiväkirjan analyysissa auttoi minua näkemään ilmiöstä tekemäni tulkinnat, joiden käsitin olevan riittämättömiä tutkimani yhteisön ymmärtämisessä. Olin tehnyt tulkinnat entisen tallitytön näkökulmasta. Kenttätyön aikana palasin takaisin menneisyyteen ja elin tuota aikaa kiihkeästi uudelleen. Refleksiivisyyden kautta sain avattua tulkintojani uudella tavalla: tiedostin näitä kulloisiakin tutkijan asemiani, jotka vaikuttivat päiväkirjani tekstiin ja tulkintoihin (Coffey 1999, esim. 36; myös Myerhoff \& Ruby 1982, 18).

Refleksiivisyys ja paikantuminen eivät saisi olla vain sanahelinää, jotka täytetään lausumalla muutama määre tutkijasta itsestään. Itseä ei tarvitse tuoda tekstissä joka käänteessä esiin, mutta jo implisiittinen refleksiivisyys vaikuttaa analyysiin ja luo puitteet muun muassa tulkintojen perusteellisemmalle käsittelylle. Refleksiivisyydessä 


\section{KENTTÄKOKEMUKSESTA TIEDOKSI}

kyse on ennen kaikkea tutkimuksellisesta asenteesta: tutkijan pyrkimyksestä kirjata auki omia tulkintojaan mahdollisimman tarkasti. Tutkijan on käsitettävä syvempi yhteytensä tutkimuskohteeseensa ja hahmotettava näin ne kehykset, joista käsin ilmiötä tarkastelee.

\section{VIITTEET}

1. Kattava esitys refleksiivisyyden historiasta antropologiassa ks. esim. Coffey 1999; Angrosino \& Perez 2000. Suomalaisessa perinteessä etnografisen tutkimuksen refleksiivisyyttä on tarkasteltu esimerkiksi tutkimuksissa, jotka käsittelevät koulun sukupuolittuneita käytäntöjä (Gordon ym. 2002) tai sosiaalityötä sekä muita "byrokraattisia näyttämöjä” (Eräsaari 1990; 1995).

2. Objektiivinen tutkimus vanhanaikaisen tieteenihanteen mukaisesti ei ole mahdollista. Tutkimus ei koskaan voi olla näkökulmatonta ja tutkimuskohteen ylä- ja ulkopuolella. Naistutkimuksen keskusteluissa on korostettu, että tehdäkseen objektiivista tutkimusta tutkijan on tuotava esiin omat tieteelliset lähtökohtansa eli subjektiivisuutensa. (Esim. Harding 1986: Keller 1988, esim. 141-170.)

3. Käsityksissä tiedon paikantumisesta ja subjektiivisuuden kautta saavutetussa objektiivisuudessa on kuitenkin myös ongelmia. Esimerkiksi voi kysyä: Mitä paikantuminen merkitsee? Onko riittävää kertoa alun johdannossa olevansa valkoinen heteroseksuaali? Pitäisikö jäljittää työssään käyttämiensä teoreettisten käsitteiden historia? (Rolin 2005, 102.) Helen Longino onkin tuonut esiin idean objektiivisuudesta tiedeyhteisön sosiaalisena käytäntönä, ei sellaisena, mitä yksittäinen tutkija voi saavuttaa (Longino 1990, 76-81). Paikantumista ja refleksiivisyyttä ei sovi myöskään sekoittaa tutkimuksen eettisyyteen: reflektoitu tutkimus ei ole välttämättä sen eettisempää kuin ei-reflektiivinen tutkimuskaan (vrt. Behar 1996).

4. Joskus autoetnografia on määritelty siten, että siinä tutkija keskittyy nimenomaan siihen, miten tutkijan osallistuminen tuotti tai muutti sosiaalisia suhteita ja ymmärrystä (Anderson 2006, 385). Ymmärrän kuitenkin tämän olevan vain yksi autoetnografiaa määrittävä piirre enkä tarkastele omaa työtäni autoetnografiana.

5. Tutkimus ei ole tutkittava kenttä vaan tulkinta siitä (Charmaz \& Mitchell 1997, 210; vrt. Abu-Lughod 1991, 141; ks. myös Callaway 1992, 44-45). Ilmiö ei ole tutkimuskenttänä olemassa ennen tutkijan tulkintaa (ks. Haraway 1991, 197-198; vrt. Karisto 2004, 311).

6. Intra-aktio pohjaa Niels Bohrin kvanttifysiikkaan, jossa teoretisoitiin havainnon kohteen ja havaitsijan välistä eriytymättömyyttä ilmiön muodostamisessa. Bohr osoitti, miten oleellisella tavalla havaintoväline vaikuttaa siihen, miten fyysiset ilmiöt maailmassa meille ilmenevät. Bohr käytti termiä ilmiö viittaamaan tietynlaiseen kokonaisuuteen: objektin ja havaintoapparaatin vuorovaikutukseen, joka muodostaa eriytymättömästi itse tutkittavan ilmiön (Barad 1998, 95).

7. Intra-aktiivisuus on liitettävissä myös luonnehdintoihin tutkimuksen kentästä, jonka ymmärrän siten kuin esim. Jyrki Pöysä on kuvannut: kenttä on tutkijan ja tutkimuk- 


\section{Karolitna OJANEN}

sen kohteeksi asetettujen ihmisten suhde eli se konstruoituu vuorovaikutuksessa (Pöysä 2004, 25; myös Hastrup 1992, 117).

8. Analysoimani esimerkit kentältä ovat selosteita kenttäpäiväkirjani merkinnöistä.

9. Anderson 2006, 385. Autoetnografioille on vaikea löytää yhtä kattavaa määritelmää. Analyyttisen etnografian, uuden etnografian ja autoetnografian eroista ks. Coffey 2002, 327-328; Anderson 2006, 373. Itsensä paikantaminen ja refleksiivisyys ovat keskeisiä nykyisissä tutkimuksissa, mutta autoetnografiat ovat yhä melko marginaalisia ja niitä on myös kritisoitu runsaasti (Coffey 1999, 18, 156). Autoetnografioita esim. Karp 1996; Ellis \& Bochner 2000; 1996.

10. Ks. Coffey 1999, 138 (ilmiön ymmärtämisen ihanuudesta ja kamaluudesta).

11. Tulkinnan nimeäminen vääräksi tai oikeaksi on etnografiassa tietysti ongelmallista, mutta tässä haluan tällä erottelulla tehdä selväksi, että päiväkirjaan kirjaamani tulkinta ei vastannut yhteisön järjestystä vaan se muotoutui uppoutuessani muistoihin lapsuuteni ja nuoruuteni tallityttöyhteisöstä. Minulle tulkinta oli tuossa kontekstissa, "silloin, siellä", oikea ja käypä.

12. Jay Prosser on käsitellyt ideaa ruumiin muistosta, jonka mukaan voimme metaforisesti ja kirjaimellisesti muistaa ihon kautta, mikä voi lisätä tietoa tutkittavasta kulttuurista (Prosser 2001, 52; ks. myös Ahmed \& Stacey 2001, 5; myös Behar 1996, 23; Gothóni 1997, 144). Tällaista kokemuksellista tietoa on edellisen esimerkin lisäksi vaikka se, miten karsinoita siivotessa en ensin jaksanut työntää kottikärryjä lantalaan, kunnes yhtäkkiä muistin, miten sen tein 8-vuotiaana: ota vauhtia, juokse etukenossa, kyynärpäät vähän yli 90 asteen kulmaan ja kippaa. Menneisyyteni tallityttönä eli siis myös ruumiillisesti pienistäkin vihjeistä.

\section{LÄHTEET}

\section{Tutkimusaineistot}

Karoliina Ojasen kenttäpäiväkirja vuonna 2006 varsinaissuomalaiselta ratsastuskoululta.

Tekstissä on viitattu merkintöihin seuraavilta päiviltä: 25.7.2006, 11.8.2006, 20.6.2006, 21.6.2006. Aineisto tekijän hallussa.

Teemahaastattelut

Haastattelija: Karoliina Ojanen.

Haastattelunauhat ja litteraatiot ovat haastattelijan hallussa.

- Milja, 14 vuotta. Haastateltu Turussa 13.2.2005.

- Satu, 20 vuotta. Haastateltu Turussa 5.5.2005.

- Sanna, 25 vuotta. Haastateltu Turussa 11.5.2005. 


\section{KENTTÄKOKEMUKSESTA TIEDOKSI}

\section{Kirjallisuus}

ABU-LUGHOD, LILA 1991: Writing Against Culture. - Fox, Richard (ed.), Recapturing Anthropology. Working in the Present. Santa Fe: School of American Research.

ADKINS, LISA 2002: Reflexivity and the Politics of Qualitative Research. - May, Tim (ed.), Qualitative Research in Action. London: Sage.

AHMED, SARA \& STACEY, JACKIE (eds.) 2001: Thinking through the Skin. London: Routledge.

ANDERSEN, LEON 2006: Analytic Autoethnography. - Journal of Contemporary Ethnography 35(4).

ANGROSINO, MICHAEL V. \& MAYS DE PEREZ KIMBERLY A. 2000: Rethinking Observation: From Method to Context. - Denxin K. Norman \& Lincoln Yvonna S. (eds.), Handbook of Qualitative Research. London: Sage.

ARO, LAURA 1996: Minä kylässä. Identiteettikertomus haastattelututkimuksen folklorena. Suomalaisen Kirjallisuuden Seuran Toimituksia 650. Helsinki: Suomalaisen Kirjallisuuden Seura.

ATKINSON, PAUL 2006: Rescuing Autoethnography. - Journal of Contemporary Ethnography 35(4).

BARAD, KAREN 1998: Getting Real: Technoscientific Practices and the Materialization of Reality. - A journal of Feminist Cultural Studies 10(2).

BEHAR, RUTH 1996: The Vulnerable Observer. Boston: Beacon Press.

CALLAWAY, HELEN 1992: Ethnography and Experience: Gender Implications in Fieldwork and Text. - Callaway, Helen \& Okely, Judith (eds.), Anthropology and Autobiography. London: Routledge.

CASSIDY, REBECCA 2002: The Sport of Kings. Kinship, Class and Thoroughbred Breeding in New Market. Cambridge: Cambridge University Press.

CHARMAZ, KATHY \& MITCHELL, RICHARD G. JR. 1997: The Myth of Silent Authorship: Self, Substance, and Style in Ethnographic Writing. - Hertz, Rosanna (ed.), Reflexivity and Voice. Thousand Oaks: Sage.

COFFEY, AMANDA 1999: The Ethnographic Self. London: Sage.

- 2002: Ethnography and Self: Reflections and Representations. - May, Tim (ed.), Qualitative Research in Action. London: Sage.

CONAWAY, MARY ELLEN 1986: The Pretense of the Neutral Researcher. - Whitehead, T. L. \& Conaway, M. E. (eds.), Self, Sex, and Gender in Cross-Cultural Fieldwork. Chicago: University of Illinois Press.

DAVIES, CHARLOTTE 1999: Reflexive Ethnography. A Guide to Researching Selves and Others. London: Routledge.

DOUGLAS, MARY 1966: Purity and Danger. London: Routledge and Kegan Paul. DRISCOLL, CATHERINE 2002: Girls. Feminine Adolescence in Popular Culture and Culture Theory. New York: Columbia University Press.

ELLIS, CAROLYN \& BOCHNER, ARTHUR P. 1996: Composing Ethnography. Alternative Forms of Qualitative Writing. London: Sage.

- 2000: Autoethnography, Personal Narrative, Reflexivity: Researcher as Subject. - Denxin, K. Norman \& Lincoln, Yvonna S. (eds.), Handbook of Qualitative Research. London: Sage. 


\section{Karolitna Ojanen}

ERÄSAARI, LEENA 1990: Nilkin naamio - sosiaaliraportti. Tutkijaliiton julkaisusarja 62. Helsinki: Tutkijaliitto.

- 1995: Kohtaamisia byrokraattisilla näyttämöillä. Helsinki: Gaudeamus.

FINE, GARY A. 1987: With the Boys. Little League Baseball and Preadolescent Culture. Chicago: The University of Chicago Press.

FINGERROOS, OUTI 2003: Refleksiivinen paikantaminen kulttuurien tutkimuksessa. - Elore. 10(2) [online]. < http://cc.joensuu.fi/ loristi/2_03/fin203c.html > [25.5.2007.]

FORSBERG, LENA 2007: Att utveckla handlingskraft. Om flickors identitetsskapande processer $i$ stallet. Luleå: Luleå Tekniska Universitet.

GORDON, TUULA \& LAHELMA, ELINA \& TOLONEN, TARJA \& HOLLAND, JANET 2002: Katseelta piilossa. Hiljaisuus ja liikkumattomuus kouluetnografin havainnoissa. - Aaltonen, Sanna \& Honkatukia, Päivi (toim.), Tulkintoja tytöistä. Tietolipas 187. Helsinki: Suomalaisen Kirjallisuuden Seura.

GOTHÓNI, RÉNE 1997: Eläytyminen ja etääntyminen kenttätutkimuksessa. - Viljanen, Anna Maria \& Lahti, Minna (toim.), Kaukaa haettua. Kirjoituksia antropologisesta kenttätyöstä. Helsinki: Suomen Antropologinen Seura.

HARAWAY, DONNA 1988: Situated Knowledges. The Science Question in Feminism and the Privilege in Partial Perspective. Feminist Studies 14(3).

- 1991: Simians, Cyborgs, and Women. The Reinvention of Nature. New York: Routledge.

HARDING, SANDRA 1986: The Science Question in Feminism. Milton Keynes: Open University Press.

HASTRUP, KIRSTEN 1992: Writing Ethnography: State of the Art. - Callaway, Helen \& Okely, Judith (eds.), Anthropology and Autobiography. London: Routledge.

HASTRUP, KIRSTEN \& HERVIK, PETER 1994: Introduction. - Hastrup, Kirsten \& Hervik, Peter (eds.), Social Experience and Anthropological Knowledge. London: Routledge.

HATAKKA, MARI 2004: “Kun on tunteet” Lukemisen kokemus metodisena mahdollisuutena. - Kurki, Tuulikki (toim.), Kansanrunousarkisto, lukijatja tulkinnat. Suomalaisen Kirjallisuuden Seuran Toimituksia 1002. Helsinki: Suomalaisen Kirjallisuuden Seura.

HERVIK, PETER 1994: Shared Reasoning in the Field: Reflexivity beyond the Author. - Hastrup, Kirsten \& Hervik, Peter (eds.), Social Experience and Anthropological Knowledge. London: Routledge,.

HERTZ, ROSANNA (ed.) 1997: Reflexivity and Voice. Thousand Oaks: Sage.

JÄRVILUOMA, HELMI \& VILKKO, ANNI \& MOISALA, PIRKKO 2006: Tutkimustulosten kirjoittaminen ja sukupuoli. - Kupiainen, Tarja \& Vakimo, Sinikka (toim.), Välimatkoilla. Kirjoituksia etnisyydestä, kulttuurista ja sukupuolesta. Joensuu: Suomen Kansantietouden Tutkijain Seura.

KARISTO, ANTTI 2004: Kenttäkokemuksia Costa del Solilta. - Laaksonen, Pekka \& Knuuttila, Seppo \& Piela, Ulla (toim.), Kenttäkysymyksiä. Kalevalaseuran vuosikirja 83. Helsinki: Suomalaisen Kirjallisuuden Seura. 


\section{KENTTÄKOKEMUKSESTA TIEDOKSI}

KARP, DAVID 1996: Speaking of Sadness. Oxford: Oxford University Press. KELLER, EVELYN FOX 1988: Tieteen sisarpuoli. Tampere: Vastapaino. [1986] KOIVUNEN, ANU \& LILJESTRÖM, MARIANNE 1996: Paikantuminen. - Koivunen, Anu \& Liljeström, Marianne (toim.), Avainsanat. 10 askelta feministiseen tutkimukseen. Tampere: Vastapaino.

KOKKO, SIRPA 2007: Käsityöt tyttöjen kasvatuksessa naisiksi. Joensuu: Joensuun yliopistopaino.

KORTTEINEN, MATTII 1992: Kunnian kenttä. Helsinki: Hanki ja jää.

KÄYHKÖ, MARI 2006: Siivoojaksi oppimassa. Etnografinen tutkimus työläistytöistä puhdistuspalvelualan koulutuksessa. Joensuu: Joensuu University Press.

LILJESTRÖM, MARIANNE 2004: Feministinen metodologia - mitä se on? - Liljeström, Marianne (toim.), Feministinen tietäminen. Keskustelua metodologiasta. Tampere: Vastapaino.

LONGINO, HELEN 1990: Science as Social Knowledge: Values and Objectivity in Scientific Inquiry. Princeton N. J.: Princeton University Press.

MYERHOFF, BARBARA \& RUBY, JAY 1982: Introduction. - Ruby, Jay (ed.), A Crack in the Mirror. Reflexive Perspectives in Anthropology. Philadelphia: University of Pennsylvania Press.

NYSTRÖM, EVA 2007: Reflexive Writing and the Question of 'Race'. An intellectual journey for a Swedish researcher. - Andersson, Åsa \& Johansson, Eva E. (eds.), Present Challenges in Gender Research. Umeå: National School of Gender Research.

OJANEN, KAROLIINA 2005: Tallitytöt. Harrastus tyttöyksien tekemisenä. - Saarikoski, Helena (toim.), Leikkeikentiltä. Lastenperinteen tutkimuksia 2000-luvulta. Tietolipas 208. Helsinki: Suomalaisen Kirjallisuuden Seura.

— 2006: "Mitä sit tarvii alkaa siäl esittämää yhtää mittää”. Tallityttöjen sukupuoliperinne performatiiveina. - Naistutkimus 19(1).

OKELY, JUDITH 1994: Vicarious and Sensory Knowledge of Chronology and Change: Ageing in Rural France. - Hastrup, Kirsten \& Hervik, Peter (eds.), Social Experience and Anthropological Knowledge. London: Routledge.

ORMOND, ADREANNE 2004: Beneath the Surface of Voice and Silence: Researching the Home Front. - Harris, Anita (ed.), All about the Girl. London: Routledge. PROSSER, JAY 2001: Skin Memories. - Ahmed, Sara \& Stacey, Jackie (eds.), Thinking through the Skin. London: Routledge

PYSTYNEN, VENLA 2007: Suomenhevonen ratsuna. - Pesonen, Hannu \& Hankimo, Olavi \& Pystynen, Venla \& Pesonen, Riikka: Lïnaharja. Suomenhevosen taival. Helsinki: Otava.

PÖYSÄ, JYRKI 2004: Historian etnografiaa Vienassa. - Laaksonen, Pekka \& Knuuttila, Seppo \& Piela, Ulla (toim.), Kenttäkyysymyksiä. Kalevalaseuran vuosikirja 82. Helsinki: Suomalaisen Kirjallisuuden Seura.

ROLIN, KRISTINA 2005: Tutkimuksen näkökulmasidonnaisuuden paradoksi. Husu, Liisa \& Rolin, Kristina (toim.), Tiede, tieto ja sukupuoli. Helsinki: Gaudeamus. RUDIE, INGRID 1994: Making Sense of New Experience. - Hastrup, Kirsten \& Hervik, Peter (eds.), Social Experience and Anthropological Knowledge. London: Routledge. 


\section{Karolina Ojanen}

SAUKKO, PAULA 2003: Doing Research in Cultural Studies. An Introduction to Classical and New Methodological Approaches. London: Sage.

SCHWALBE, MICHAEL 1996: The Mirrors in Men's Faces. - Journal of Contemporary Ethnography 25(1).

SUOJANEN, PÄIVIKKI 1997: Työkaluna tutkijan persoona. - Viljanen, Anna Maria \& Lahti, Minna (toim.), Kaukeaa haettua. Kirjoituksia antropologisesta kenttätyöstä. Helsinki: Suomen Antropologinen Seura.

TOLONEN, TARJA 1992: Tyttöjen hevostallikulttuuri: faniudesta vastuunottoon. - Näre, Sari \& Lähteenmaa, Jaana (toim.), Letit liehumaan. Tyttökulttuuri murroksessa. Tietolipas 124. Suomalaisen Kirjallisuuden Seura: Helsinki.

WASSERFALL, RAHEL R. 1997: Reflexivity, Feminism, and Difference. - Hertz, Rosanna (ed.), Reflexivity and Voice. Thousand Oaks: Sage.

WHITEHEAD, T. L. \& CONAWAY M. E. (eds.), 1986: Self, Sex, and Gender in CrossCultural Fieldwork. Chicago: University of Illinois Press.

Filosofian maisteri Karoliina Ojanen on folkloristiikan tutkijakoulutettava Helsingin yliopistossa. Artikkeli on valmistunut Suomen Akatemian tutkimushankkeessa Sukupuolten tuottaminen lasten kulttuureissa (päätösnumero 122561). 